\title{
A Report on the XVII International Symposium on Glycoconjugate
}

\author{
第17回国際複合糖質シンポジウムに関する報告
}

\author{
T.N.C. Ramya and Avadhesha Surolia* \\ Molecular Biophysics Unit, Indian Institute of Science, Bangalore 560 012, INDIA \\ FAX:91-80-3600535, E-mail:surolia@mbu.iisc.ernet.in
}

The XVII symposium on Glycoconjugates organized by the Indian Institute of Science, Bangalore, India in association with National Centre for Biological Sciences, Bangalore and Jawaharlal Nehru Centre for Advanced Scientific Research, Bangalore, covered topics ranging from sugars in pathogenesis, therapy and gene targeting to glycan synthesis. The quantity and quality of research in this area clearly showed that glycomics is definitely on the road to being the 'in' topic, now that the initial excitement over genomics and proteomics is fast abating. The symposium held in the sprawling green wildernesses of the Indian Institute of Science, Bangalore, India during Jan 12 to 15, 2003 saw active researchers galore in the area of glycobiology as well as young scientists in the making from several countries participating with unveiled enthusiasm. The days were packed with lectures in four parallel sessions, marked by refreshingly open and titillating discussions, a veritable feast to the ears, and the evenings were, as one senior foreign delegate remarked, 'Indian hospitality at its best'.... well, need one say more?

Getting down to brass tacks, what were the key research points made at the symposium?? In lieu of the growing interest in the role of protein- and lipid-linked carbohydrates in biological processes, Raymond Dwek, Oxford University, Oxford struck just the right note with his keynote address on the use of imino sugars to target glycosylation enzymes, which has demonstrated considerable promise in the treatment of viral infections such as hepatitis B, hepatitis C, Dengue and Japanese encephalitis, and glucosphingolipid storage disorders such as Gaucher disease. Equally stimulating to the gray cells was the International Glycoconjugates Organization Award lecture by Pamela Stanley, Albert Einstein College Medicine, New York whose research beginning with the glycosylation-deficient mammalian cell mutants and employing current transgenic technology coupled with conventional histochemical staining in mouse embryos have led to the definition of the earliest stage of development at which complex $N$-glycans are required. Y. C. Lee, Johns Hopkins University, in his GlycoXVII lecture, gave an interesting insight into an ever-increasingly used application - the humanization of glycoprotein production in insect cell lines.

*Corresponding author
第17回複合糖質シンポジウムは、National Centre for Biological Sciences (バンガロール)および Jawaharlal Nehru Centre for Advanced Scientific Research(バンガローる) の後援で、Indian Institute of Science (インド、バンガロール) が主催した。ここでは、 疾病原因としての糖、治療ならびにグリカン合成を標的とした 遺伝子に関するトピックスが話し合われた。今回発表されたグ リコミクス領域の研究の質の高さや量の多さは、明らかにこの 領域が科学の中心となる道をはっきりたどっていることを明確 に示して扔り、今や、ゲノミクスやプロテオミクスに関する当 初の興奮は急速に潮が引いて行くように見えた。第 17 回複合糖 質シンポジウムは、2003 年1月 12日から 15 日まで、Indian Institute of Science (バンガロール)が位置する広大な緑の原野で開 催された。数力国から糖質生物学分野で積極的に研究している 研究者や若い科学者が多数参加し、活発な意見交換がなされ た。4つのセッションが並行して行われ、毎日、講演がぎっし り詰まって充実しており、オープンで興味をそそる新鮮なディ スカッションが行われた。まさに知識欲を満たす知の饗宴で あったと言えるだろう。夕暮れ時はと言いえば、ある外国から の参加者が ‘インド人のホスピタリティーは最高だ と述べて いたが・..もうこれ以上の他言は要しないだろう。

要点をまとめてみよう。このシンポジウムで話題となった キーポイントは何だったのであろうか? 生体プロセスに打ける タンパク質および脂質と結合した糖質の役割への関心が高まっ ている代わりに、オクスフォード大学 (オクスフォード)の Raymond Dwekは、基調講演で、イミノ糖を用いて、糖化酵素を ターゲットとすることに関して、まさに適切な指摘を行った。 これは、 $\mathrm{B}$ 型肝炎や $\mathrm{C}$ 型肝炎、デング、日本脳炎などのウイル ス感染症や、ゴーシェ病などのスフィンゴ糖脂質蓄積障害の治 療にかなり有望であることを示した。同様の刺激を与えてくれ たものが、Albert Einstein College Medicine (ニューヨーク)の Pamela Stanleyによる国際複合糖質機関賞の受賞記念講演であっ た。グリコシル化欠損ほ乳動物突然変異細胞から初めて、現在 では、トランスジェニック技術をマウスの胚で従来の組織化学 法と組み合わせた彼女の研究から、発生の最も初期段階でも複 合型 $N$-グリカン糖鎖の必要性が明確になった。Johns Hopkins 大 学のY.C. Leeは、彼の GlycoXVIIレクチャーの中で、盛んに応 用されるようになってきた分野、すなわち昆虫の樹立細胞系統 における糖タンパク質産生のヒト化 (humanization) に関して興 味深い洞察を行った。 


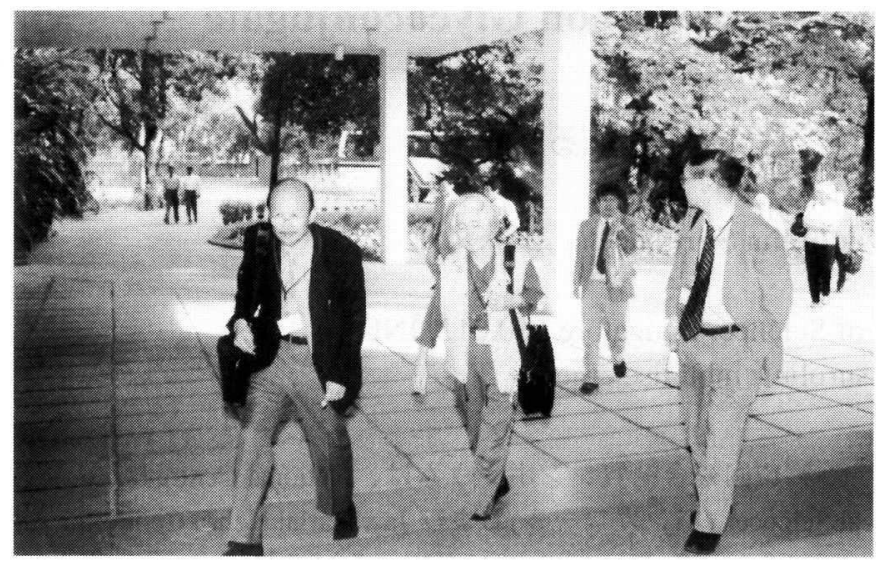

Photo 1. All roads lead to GlycoXVII.

Each of the eight plenary talks was one of their kinds, the speakers' depth of knowledge in their field as well as the meticulous research rendering them so. Ajit Varki's insights into the evolutionary aspects of sialic acid biology, G. Tettamanti's talk on sialidases, H. J. Jennings talk on the utilization of polysialic acid epitopes in vaccines against meningitis and cancer, and the umpteen other talks on sialic acid biology in the two sessions devoted to sialic acids and their role in health and disease (J. Finne, Y. Suzuki, T. Miyagi, E. Lisowska) clearly indicated that sialic acids and its close cousin, KDN, discussed by $\mathrm{Y}$. Inoue and S. Inoue are hot favorites among glycobiologists.

Another upcoming topic was definitely lectins. M. Vijayan's plenary talk on crystallographic studies of plant lectins on $13^{\text {th }}$ Jan kicked off several sessions on lectins - sessions on the structural basis of the carbohydrate specificities of lectins and glycosyltransferases (R. Loris, D. M. Salunke, J.M. Rini and K. R. Acharya), lectins and quality control of protein folding (J. Roth and W. Lennarz), lectin-carbohydrate recognition (E. J. M. Van Damme, S. Perez, A. Imberty and J. G. M. Bolscher), ligand recognition by C-type lectins and siglecs ( $\mathrm{T}$. Irimura, K. Drickamer, J. Paulson and S. Kelm), galectins and C-type lectins (M. Taylor, H. Leffler and Y. Zick), novel modes of carbohydrate recognition (G. R. Vasta, H. Kaku), and carbohydrate-carbohydrate (F. G. Vliegenthart and P. Kammerling) and lectin-sugar recognition and the Bangalore Structural Glycobiology Highlights with talks by the host institute's young and budding scientists.

Topics on glycosylation closely followed suit...there were talks on the structural basis of catalysis and specificity, biosynthesis trafficking and localization, origin and evolutionary aspects, and functions of glycosyltransferases, and, glycosylation and modulation of cellular functions such as in carcinogenesis, signaling and parasite biology by glycosylation in the sessions

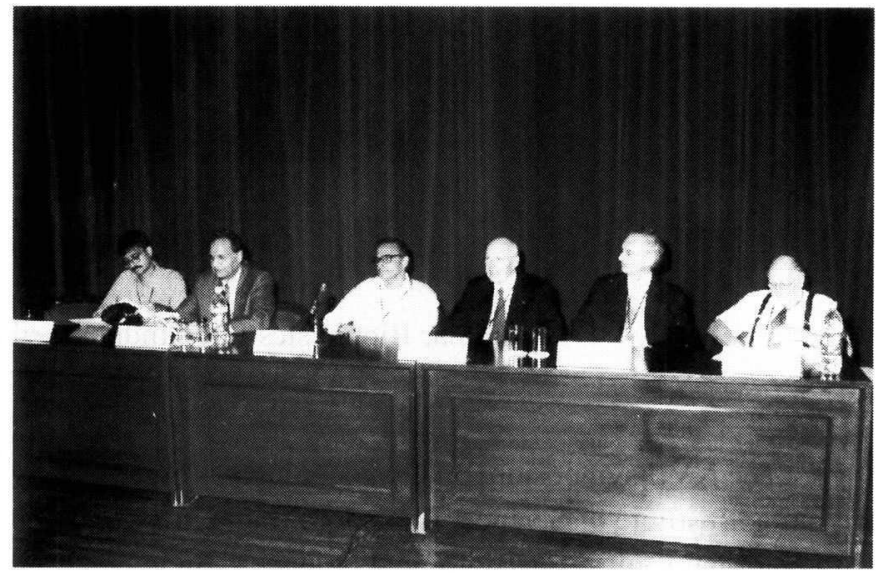

Photo 2. GlycoXVII's bigwigs met together.

8つのプレナリー講演は、講演者それぞれの分野での知識 の深さと、それを可能にした注意深い研究を示すものであっ た。Ajit Varkiのシアル酸生物学の進化的側面に関する講演、シ アリダーゼに関する G. Tettamanti の講演、髄膜炎やがんに対す るワクチンへのポリシアル酸エピトープの活用に関するH.J. Jenningsの講演、さらに、シアル酸と、健康および疾病における シアル酸の役割についての 2 つセッションでのシアル酸の生 物学に関するいくつかの講演 (J. Finne, Y. Suzuki, T. Miyagi, E. Lisowska)では、シアル酸およびそれと密接な関係にあるKDN が、これはY. Inoue と S. Inoueにより論じられたが、糖鎖生物 学者の中でホットな研究対象であることを示していた。

もう一つの注目を集めた話題は、レクチンであつた。1月13 日に行われた植物レクチンの結晶構造解析に関する M. Vijayan のプレナリー講演から、レクチンに関するいくつかのセッショ ンが開始された。これらは、レクチンとグリコシルトランス フェラーゼの糖鎖認識特異性にするセッション(R. Loris, D. M. Salunke, J.M. Rini および K. R. Acharya)、レクチンとタンパク質 折りたたみの品質管理に関するセッション(J. Roth およびW. Lennarz)、レクチンー糖質認識 (E. J. M. Van Damme, S. Perez, A. Imberty およびJ. G. M. Bolscher)、C-型レクチンとシグレックに よるリガンド認識 (T. Irimura, K. Drickamer, J. Paulson拉よび S. Kelm)、ガレクチンとC-型レクチン (M. Taylor, H. Leffler拉よび Y.Zick)、糖質 (G. R. Vasta, H. Kaku)、糖質-糖質 (F. G. Vliegenthart およびP. Kanmerling) およびレクチンー糖認識に関する新規モ デル、さらに主催研究所の若い研究者によるBangalore Structural Glycobiology Highlights (バンガロール構造糖鎖生物学ハイライ ト)などである。

グリコシル化に密接に関連する発表として、糖転移酵素と グリコシル化のセッションでは、糖転移酵素の触媒作用と特異 性の構造的基礎、生合成、細胞内交通と局在、起源および進化 的側面、機能、さらに、タンパク質の糖鎖修飾による発がん、 シグナル伝達、および寄生虫生物学などに対する影響などが あった。H. Narimatsuは、プレナリー講演で、ノックアウトマウ 


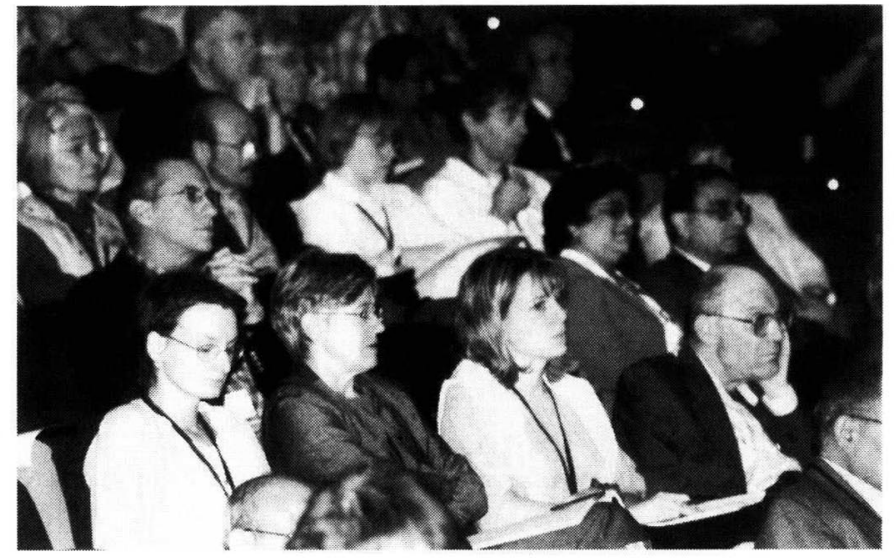

Photo 3. Great minds at work.

on glycosyltransferases and glycosylation. H. Narimatsu in his plenary talk focused on the studies conducted in his laboratory on the expression, localization and function of Fucosyltransferase 9 in mice employing knockout mice and other standard tools of molecular biology and bioinformatics. Other talks on glycosylation and glycosyltransferases were by K. Sugahara, J. M. Rini, S. Hase, R. D. Cummings, K. Brew, T. Suzuki, S. Moore, K. von Figura, V. Pozsgay, N. Taniguchi, I.G. Bravo, R. Stern, S. Bishayee, S. Basu, R. T. Schwarz and R. Blumenthal

Carbohydrates in pathogenesis and pathobiochemistry were also delved in detail in the sessions on 'carbohydrates, malaria pathogenesis and molecular mimicry' and 'bacterial cell surface and vaccines'. M. McConville in his plenary talk elucidated the importance of the glycosyl-phosphatidylinositol anchored glycoproteins and proteoglycans and free GPI glycolipids as virulence determinants in many pathogenic microbes. Ongoing studies in his laboratory showed that stage-specific changes in the levels of expression of GPI enzymes, which determine the composition of the surface coat, are regulated at the level of protein trafficking and turnover in a novel lysosomal compartment. Studies on glycosphingolipids by K. Sandhoff brought up interesting findings, as his plenary talk revealed, and led to a new concept of the topology and the biochemical pathway for the generation of the extracellular water-permeability barrier in the stratum corneum of land dwelling animals.

Carbohydrates play a significant role in cell adhesion and signaling, too, and this was the topic of several talks including that of S. Hakomori. Glycosphingolipids are clustered and noncovalently associated with signal transducer molecules and hydrophobic proteins to form membrane domains involved in GSL-dependent cell adhesion coupled with signal transduction through activation of transducer molecules to form glycosynapses. The microdomains formed in such a situation

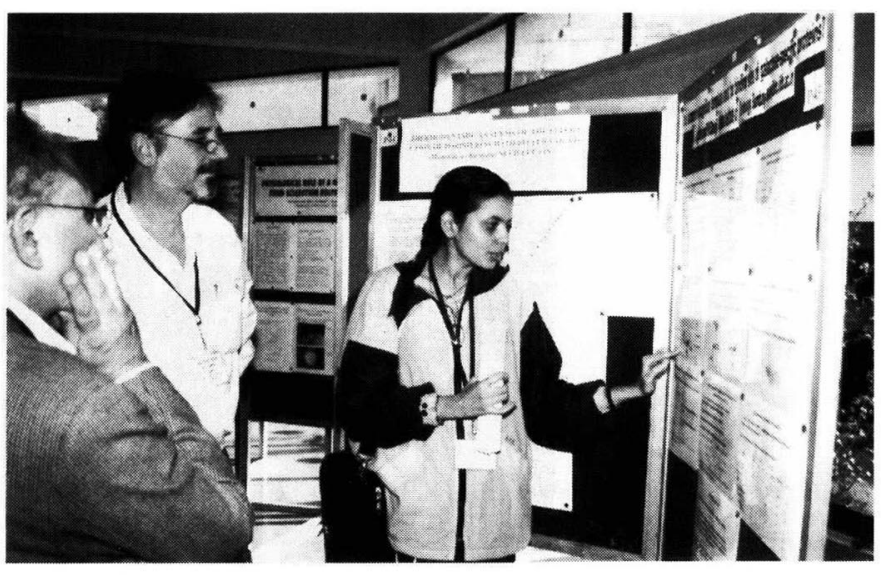

Photo 4. GlycoXVII's young talent show a poster.

スと分子生物学やバイオインフォーマティクスの標準的なッー ルを用いたマウスフコシルトランスフェラーゼ 9の発現、局在 性、および機能に関して、自らの研究を中心に述べた。グリコ シル化と糖転移酵素に関する講演として、他には、K. Sugahara,

J. M. Rini, S. Hase, R. D. Cummings, K. Brew, T. Suzuki, S. Moore, K. von Figura, V. Pozsgay, N. Taniguchi, I.G. Bravo, R. Stern, S. Bishayee, S. Basu, R. T. Schwarz およびR. Blumenthalのものがあっ た。

発病と病態生化学における糖質についても、“糖質、マラ リアの病因と分子構造類似性”さらに “細菌表面とワクチン” のセッションで詳しく検討された。M. McConville は、プレナ リー講演で、多くの病原微生物の病原性決定因子として、グリ コシルホスファチジルイノシトールアンカー糖タンパク質、プ ロテオグリカンならびに遊離GPI糖脂質が重要であることを明ら かにした。彼が現実に行っている研究は、表面コートの組成を 決定づけるGPI酵素発現のステージ特異的変化が、新しいリソ ゾームコンパートメント中で起こるタンパク質の細胞内交通と 代謝回転により制御されていることを示した。K. Sandhoff はプ レナリー講演で、スフィンゴ糖脂質の研究から、陸棲動物の角 質層に扮ける細胞外水透過性バリアを形成するトポロジーおよ び生化学経路について新しい考え方がもたらされることをを述 ベた。

糖質は、細胞接着やシグナル伝達にも重要な役割を果たし ている。これに関して、S. Hakomori などによるいくつかのト ピックスがあった。スフィンゴ糖脂質はクラスターを形成し、 シグナル伝達分子や疎水性タンパク質と非共有結合して膜領域 を形成し、GSL 依存性の細胞接着に関与しており、合わせて、 トランスデューサ分子を活性化させ、グリコシナプスを形成す ることを通じて、シグナル伝達を行っている。このような状況 で形成されるマイクロドメインが、キナーゼの活性化と組み合 わせた細胞接着の可能性を与え、その結果、表現型が变化し、 


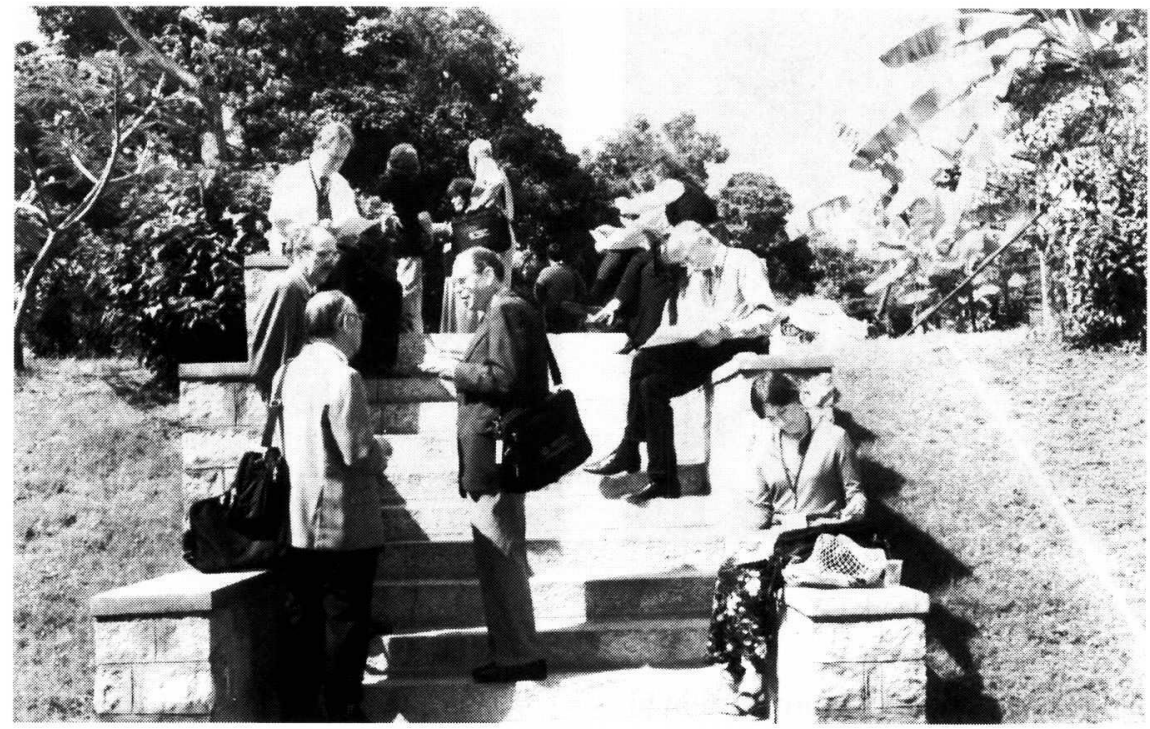

Photo 5. Where science and nature meet.

opens up possibilities for cell adhesion coupled with activation of kinases, leading to phenotypic changes, particularly in defining tumor cell malignancy. The role of sphingolipids in neuronal function cannot be overemphasized, too. S. E. Pfeiffer and A. H. Futerman dealt extensively with the regulation of myelinogenesis by galactosphingolipids, and neuronal dysfunction in glycosphingolipid storage diseases, respectively, while T. Endo discussed the relationship of mammalian $O$-mannosyl glycan to muscular dystrophy and neuronal migration disorder.

K. Kimata and several others discussed their findings on hyaluronan and other structural carbohydrates. There were innumerable talks on glycoconjugates in gene targeting, immunology and intracellular matrix and on synthesis of sugars, too. N. V. Bovin, C. Rondanino and M. Monsigny dealt with the design of multivalent neoglycoconjugates for glycobiology research, the nuclear improt of glycoconjugates upon microinjection into the cytosol of living cells, and glycofection - gene transfer using cationic glycopolymers, respectively. D. M. Salunke discussed the immunological implications and the structural basis of carbohydrate mimicry using concanavalin $\mathrm{A}$, the mannosespecific multivalent carbohydrate binding protein. Lectin-mediated innate immunity, specifically immunity mediated by mannose binding protein, a C-type lectin to tumor activity in vivo (MBP-dependent cell-mediated cytotoxicity or MDCC) was discussed by T. Kawasaki. P.H. Seeberger described an application of an automated solid-phase oligocsaccharide synthesizer developed to prepare complex $N$ - and $O$ - linked oligosaccharides, including an anti-toxin malaria vaccine from monosaccharide building blocks. S. Oscarson discussed the synthesis of high mannose, LacNAc oligomers and dendrimers, etc.
特に、腫瘍細胞の悪性を決定する表現型の変化をもたらす。神 経機能に果たすスフィンゴ脂質の役割も非常に重要である。 $\mathrm{S}$. E. PfeifferとA. H. Futermanは、それぞれ、ガラクトスフィンゴ脂 質によるミエリン形成の制御とスフィンゴ糖脂質蓄積疾患にお ける神経機能障害について広範な検討を紹介し、一方、T. Endo は、ほ乳動物のO-マンノシルグリカンと筋ジストロフィーおよ び神経移動障害との関係について論じた。

K. Kimataらは、ヒアルロナンおよび他の構造糖質に関する 彼らの知見について述べた。遺伝子ターゲティング，免疫学、 および細胞内マトリックスにおける複合糖質や糖質合成に関し ても多数の発表があった。N. V. Bovin, C. Rondaninoおよび M. Monsignyは、糖鎖生物学研究のための多価の新複合糖質のデザ イン、生きている細胞の細胞質ゾルに微小注入した後の複合糖 質への核への取り达み、および、glycofectionつまり、陽イオン 糖質ポリマーを使った遺伝子導入についてそれぞれ論じた。D. M. Salunkeは、マンノース認識多価糖質結合タンパク質である concanavalin Aを用いた糖質構造類似性の免度学的意義と構造的 基礎について論じた。T. Kawasaki は、レクチンが介在する先天 免疫、マンノース結合蛋白、C-型レクチンが介在する in vivo で の腫瘍活性に対する特異免疫（MBP-依存的細胞性細胞傷害作用 (マンナン結合タンパク質依存的細胞性細胞傷害作用、 MDCC）について論じた。P.H. Seebergerは、モノサッカリドの ブロックから、アンチトキシンマラリアワクチンなどのN-なら びにO-結合オリゴ糖を合成するために開発された自動化固相才 リゴ糖合成装置の応用について発表した。S. Oscarsonは、高マ ンノース、LacNAcオリゴマーおよびデンドリマーなどの合成に ついて述べた。 


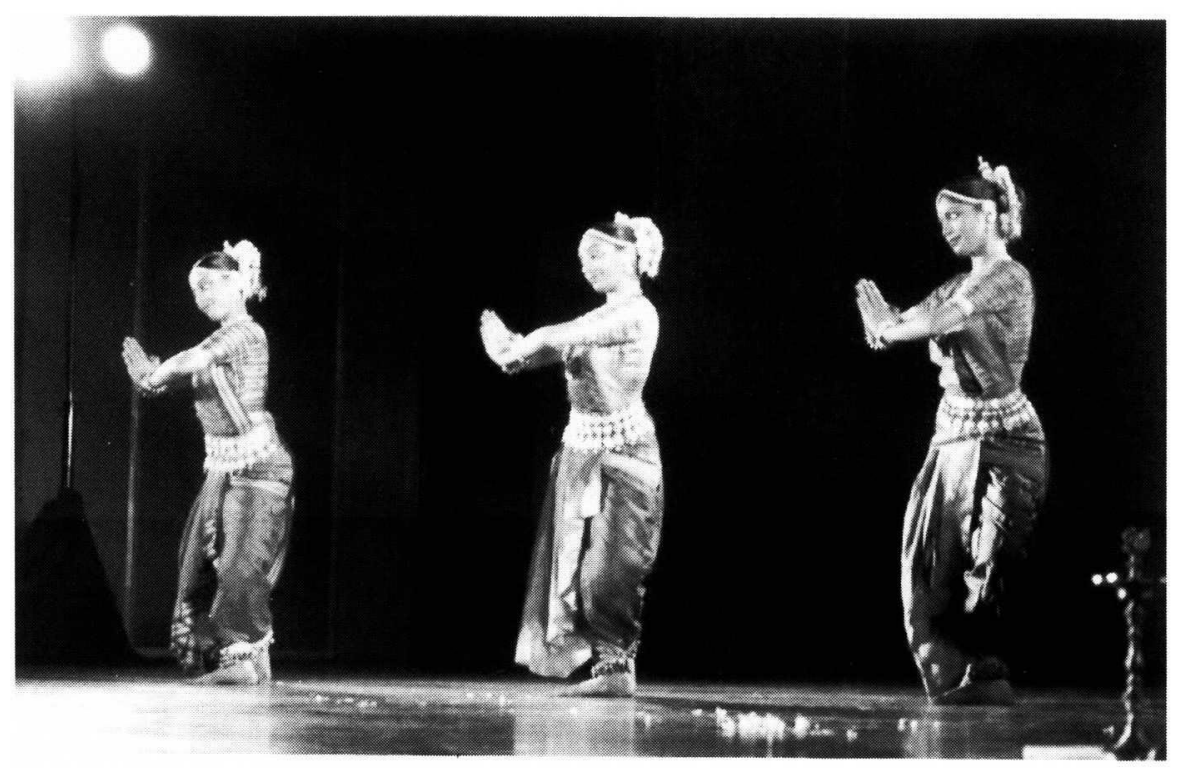

Photo 5. Dancing to Indian tunes .

But the newest and the hottest topic on the charts was definitely glycomics and glycotechnology. Now that the human genome sequence is out and we know that the whole genome codes for less than 50 thousand proteins, we cannot overemphasize the role of oligosaccharide chains as diversifiers and modulators of the functions of proteins in health and disease. The challenge remains to determine roles of the oligosaccharide chains as ligands and biological response regulators. Lipid-linked oligosaccharides can be the basis of a carbohydrate microarray system that is applicable to both structurally defined oligosaccharides and to those derived from biological sources, glycoproteins, cells and even a whole organ, as Ten Feizi revealed in her talk. Further, D. Wang presented a biochip platform that is suitable for the large scale immobilization of polysaccharides, glycoproteins, glycolipids, etc., without chemical conjugation, thus enabling the production of carbohydrate-based as well as protein based microarrays. N. Taniguchi presented a functional glycomic approach of the identification of target proteins and the characterization of their functional changes due to glycosylation, and S. M. Haslam talked about using ultra-high sensitivity mass spectrometric strategies for defining the primary structures of highly complex mixtures of glycopolymers. The discussion on glycomics by A. Kobata, R. Schnaar, P. Stanley, N. Sharon, Ten Feizi, Denong Wang, H. S. Conradt, P.H. Seeburger and N. Jayaraman on the concluding day of the symposium was an eye opener, and though much remains to be done to bring glycomics to the level of genomics or proteomics, the discussion was definitely a gigantic step in the right direction...All in all, a fitting conclusion to a marvelous symposium.
しかし、最新の最も熱心となった話題は、グリコミクスと グリコテクノロジーであった。ヒトゲノム配列が解明され、ゲ ノム全体で、5万種に満たないタンパク質しかコードされていな いことがわかった現在では、健康状態や疾病状態における夕ン パク質の機能付与や修飾役としてのオリゴ糖鎖の役割はいくら 強調してもしすぎることはない。リガンドや生物学的応答のレ ギュレータとしてのオリゴ糖鎖の役割を今後は解明する必要が ある。脂質結合才リゴ糖は、糖質マイクロアレーシステムの基 礎となり得るものであり、Ten Feizi が彼女の講演で明らかにし たように、このシステムは、構造的に明らかにされているオリ ゴ糖にも、生物由来の糖タンパク質、細胞、さらには臟器全体 にも応用できるものである。さらに、D.Wang は、化学的結合 なしに、多糖類、糖タンパク質、糖脂質などを大規模に固相化 するのに適したバイオチッププラットフォームを発表した。こ れを用いると、糖質ベースならびにタンパク質ベースのマイク ロアレーを製造することが可能になる。N. Taniguchiは、標的夕 ンパク質の同定とグリコシル化による標的タンパク質の機能の 変化に関する機能的グライコミクスアプローチについて論じ た。S. M. Haslamは超高感度質量分析法を用いて、グリコポリ マーの非常に複雑な混合物の一次構造を明らかにする方法につ いて発表した。A. Kobata、R. Schnaar, P. Stanley, N. Sharon, Ten Feizi, Denong Wang, H. S. Conradt, P.H. Seeburger, N. Jayaraman に よるシンポジウムの最終日のグリコミクスについての討論は極 めて注目させるものであった。ゲノミクスやプロテオミクスの 水準にまでグリコミクスを高めるには、まだ成すべきことが多 いが、検討されたことは、明らかに正しい方向への偉大な一歩 であった。素晴らしいシンポジウムにふさわしい結論であっ た。

\section{静岡県立大学薬学部}

鈴木 康夫訳 